\title{
THE NABATAEAN MINISTER SYLLAEUS IN A NEW ANCIENT NORTH ARABIAN (SAFAITIC) INSCRIPTION
}

\author{
NADA AL-RAWABDEH-SABRI ABBADI \\ Faculty of Archaeology and Tourism, the University of Jordan \\ 11942, Amman, Jordan \\ e-mail: nadaalrawabdeh@gmail.com
}

The aim of this study is to shed light on a new Ancient North Arabian inscription containing a reference to the Nabataean minister Syllaeus. This inscription is the second from the known corpus of Ancient North Arabian to mention the name of this minister, and could be dated to the last quarter of the 1st century BC. The inscription includes the rare verb $n g y$ which means "to flee".

Key words: Nabataean, Syllaeus, Jordan, Romans, Ancient North Arabian, Safaitic inscriptions.

\section{Introduction}

The stone which bears this inscription was found in Wadi al-Hašad and is situated about $45 \mathrm{~km}$ northeast of the village of as-Safawi, formerly known as H4 (see Figure 1).

While there are a number of stone cairns in the wadi, the number of cairns is unusually low when compared with the rest of the area which usually has a very high density of cairns. In terms of topography, the wadi is notably flat, being spread out over a large area. This is an area where a number of Greek, Ancient Arabian and Islamic inscriptions have been found, as well as a lot of accompanying rock art. The Safaitic inscriptions from this area are characterised in general by their length, since there is an unusually high number of long narrative inscriptions, and also by the thin scratching technique used to carve the letters, which seems to be a feature of the majority of inscriptions in this area. The inscription in this study was found approximately five hundred metres away from the only other known inscription to include the name Syllaeus ('Abbādī 1997 and 2001, see Figure 2). 


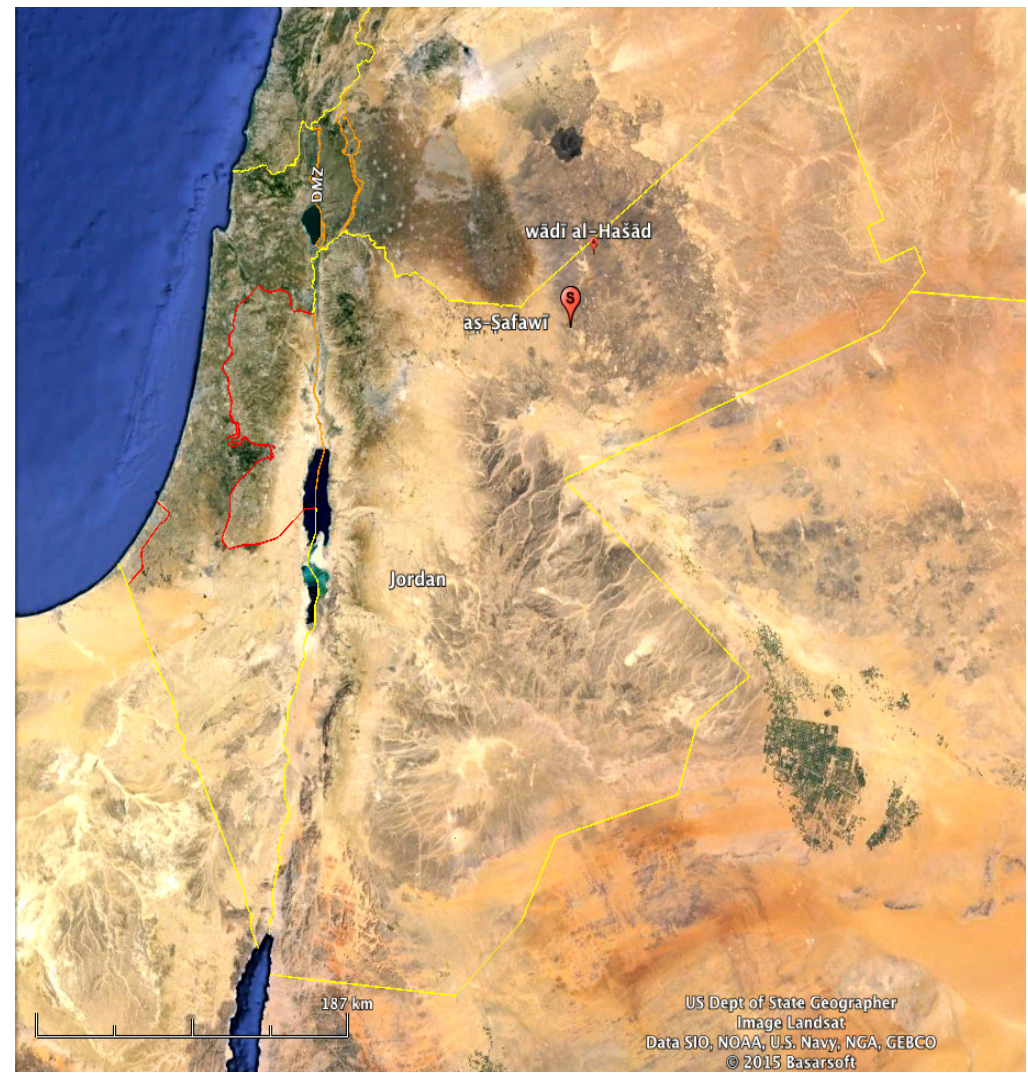

Figure 1. Map of Jordan showing the location of Wadi al-Hašad (Source: Google Earth)

\section{Form of the Inscription}

As with the vast majority of Safaitic inscriptions, this inscription (see Figures 3 and 4) is carved on a basalt stone approximately $23 \mathrm{~cm}$ by $41 \mathrm{~cm}$. The stone is loosely rectangular in shape, and the top-right corner is damaged: the first letter of the inscription should be a lam auctoris, the extremity of which is just visible next to the damaged part of the rock. Although the lam is not visible except for this very small part, it is easy to reconstruct, since most Safaitic inscriptions begin with this letter, which is followed by a personal name or genealogy and the meaning of which is "by" (Al-Jallad 2015 , pp. 4-6). There is also some damage to the top side of the rock which causes difficulty in reading all the letters from the last part of the inscription. A minor amount of scratching in the centre-right part of the rock makes the personal name $g m l$ slightly obscured, although it is still possible to read. 


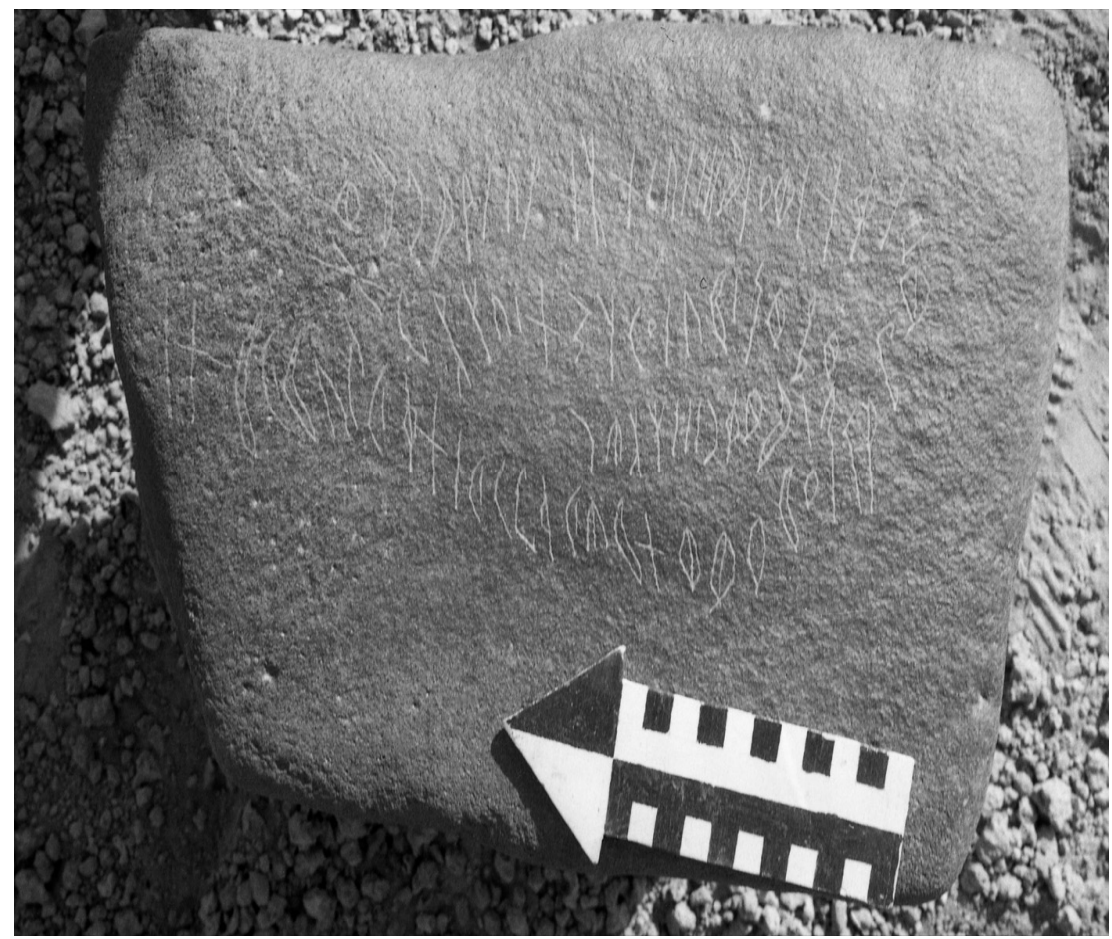

Figure 2. AbNSJ $1^{1}$

There are two inscriptions on the surface of the rock: the shorter, inscription 2, is found on the right hand edge, and the longer, inscription 1, occupies most of the space on the rock. It is probable that inscription 1 was carved before inscription 2, since the latter follows the shape of the longer one, indicating that it was carved around a pre-existing inscription. Safaitic inscriptions normally show a certain amount of respect for other inscriptions in this regard, since it is quite rare that an author writes over another author's inscription with his own.

The surface of the stone has played a role in the forming of the letters. In general, the letter forms of these two inscriptions are similar to those found in AbNSJ 1, but with some notable departures. It can be seen that the form of the letter ghain in the name $\dot{g} n m t$ is different from the same letter in the name $\dot{g} y r$ : this is on account of the rough, almost sponge-like, surface of the stone which has prevented the easy writing of the letter ghain. The inscription includes 111 letters.

\section{${ }^{1}$ Transliteration}

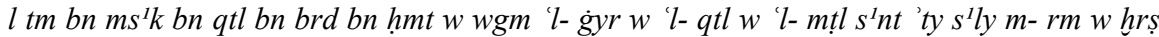
h- $s^{I} n t f h b^{\prime} l s^{I} m n \dot{g} w \underline{t} w s^{l} l m w$ qbll l- $\underline{d}{ }^{\prime} h b$

\section{Translation}

By Tm son of Ms ${ }^{1} \mathrm{k}$ son of Qtl son of Brd son of Hmt and he grieved for Giyr and for Qtl and for Mțl the year $\mathrm{S}^{1} l y$ came from Rm and he kept watching this year and so O B $1 \mathrm{~s}^{1} \mathrm{mn}$ [grant] help and security and [show] benevolence for whoever 'hb. 


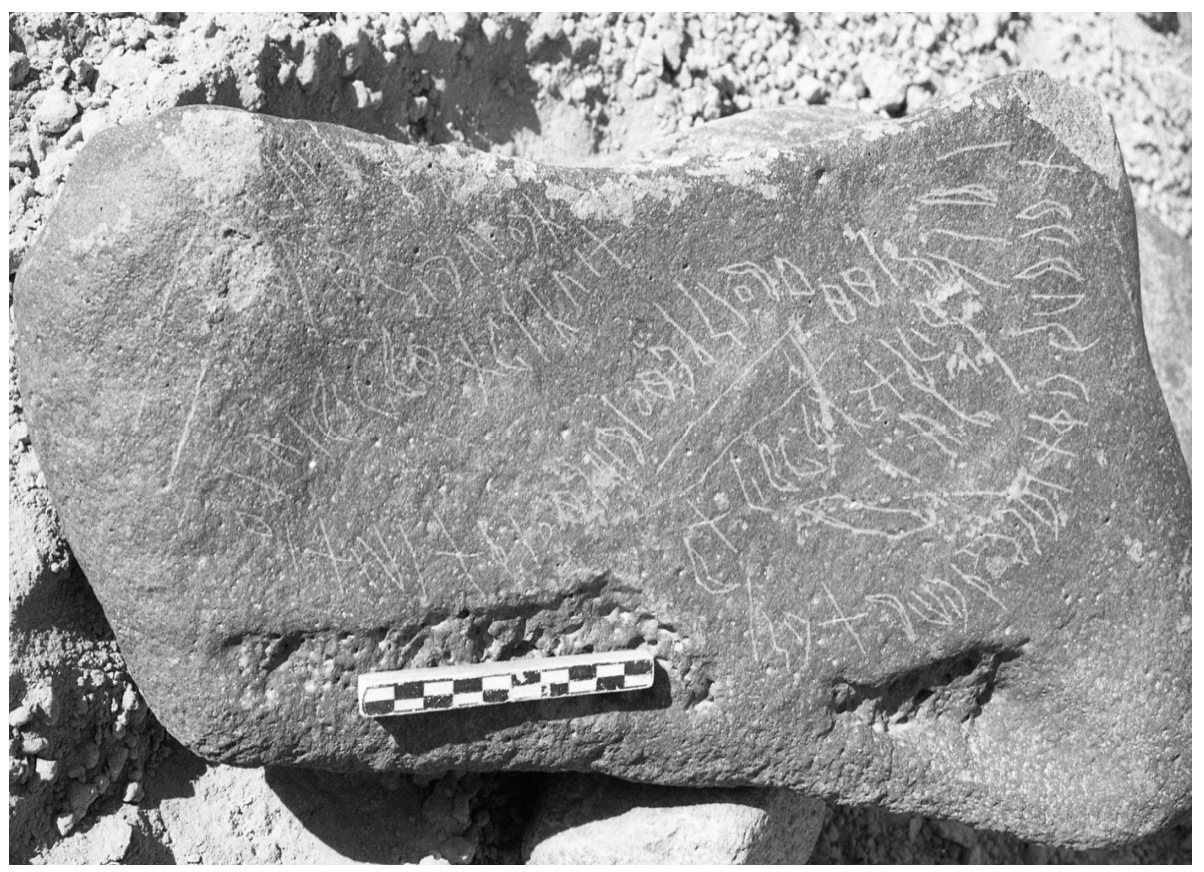

Figure 3. The stone which bears this inscription

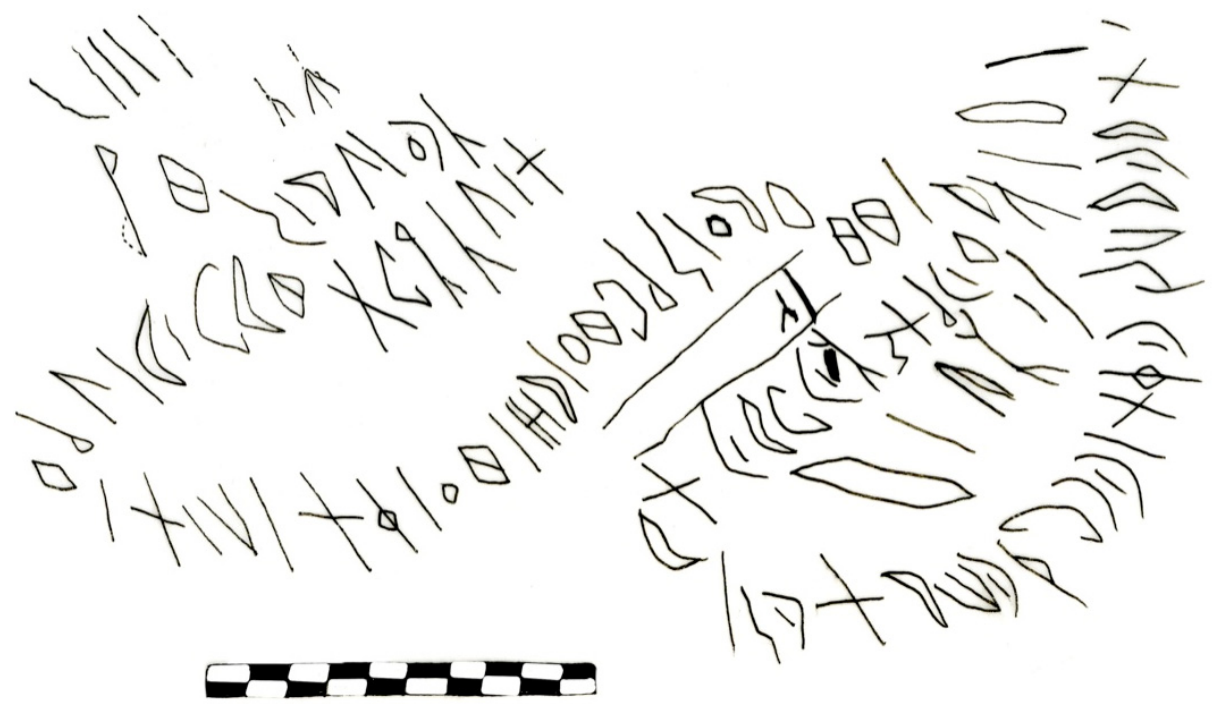

Figure 4. Tracing of the inscription 


\section{The Inscriptions}

\subsection{Inscription 1}

\section{Transliteration}

l tm bn ms'k bn qtl bn brd bn hmt bn glmt bn $m$ r bn 'fty bn gml w wgm 'l- gyr w 'l-

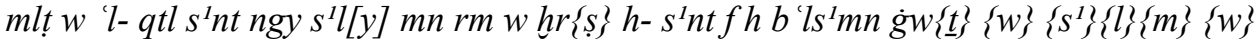
$\{q\}\{b\}\{l\}\{l\}\{l\}-\{d\}\{'\}\{h\}\{b\}$

\section{Translation}

By Tm son of Ms ${ }^{1} \mathrm{k}$ son of Qtl son of Brd son of Hmt son of Gंlmt son of Mr son of 'fty son of $\mathrm{Gml}$ and he grieved for Gyr and for Mțl and for Qtl the year $\left\{\mathrm{S}^{1} l y\right\}$ fled from $\mathrm{Rm}$ and \{he kept watching\} this year and so O B $\mathrm{B}^{1} \mathrm{mn}$ [grant] \{help\} \{and\} \{security\} \{and\} [show] \{benevolence\} \{for\} \{whoever\} \{hb\}".

\section{Commentary}

This inscription begins, as the majority of Safaitic inscriptions do, with the lam auctoris, which means "by"2.

\section{Genealogy}

The lam is usually followed by a genealogy in Safaitic inscriptions. These vary between short genealogies, maybe even just one name, and long ones; the longest inscription on record contains twenty-five names in the genealogy. It is interesting to note that the same genealogy appears on seven different stones in the same area as this inscription; assuming that the vocalisation of these names is the same, it is highly likely that the same person has authored all of these inscriptions. All of the personal names included in this genealogy are known from the Safaitic and Ancient North Arabian corpora ('Abbādī 1997 and 2001).

One interesting find from this inscription is that it allows us to correct the reading of KRS 650 which previously read $\dot{g} l m t ~ b n ~ m r ~ b n ~ ' f t l$; the reading was considered dubious by King who simply recorded it as ' $f t\{$. . but we can now reconstruct the personal name 'fty with confidence based on the reading from this inscription.

${ }^{2}$ For a discussion on the various possibilities, see Al-Jallad (2015, pp. 4-6) and Macdonald (2006, pp. 294-295). 


\section{Narrative}

The inscription contains three verbs: wgm, "he grieved" (HCH 24) and hrș, "he kept watching" (SIJ 534), as well as the rare verb ngy which we understand to mean "he fled" (LP 407). In the first phrase, $w$ wgm ' $l$ - gyr w ' $l-m l t w$ ' $l$ - qtl, "and he grieved for Gyr and for Mțl and for Qtl", we find the $w$ meaning "and", which is the usual conjunction to introduce the narrative section of the inscription in Safaitic, and the preposition ' $l$, meaning "for" in this case, which usually follows the verb $\mathrm{wgm}$ "to grieve for". The same three names are grieved for in this inscription as in AbNSJ 1 but the names are in a different order. Here we find ' $l-\dot{g} y r w$ ' $l-m l t w$ ' $l-q t l$ "for Ġyr and for Mṭl and for Qtl" whereas in AbNSJ 1 the inscription reads wgm 'l- gyr w 'l- qtl w ' l$m t ̦ l$ "for Gyr and for Qtl and for Mțl".

After the wgm portion of the narrative, the writer dates his inscription using the dating formula $s^{1} n t n g y s^{1} l[y] \mathrm{mn} r m$ "the year $\left\{\mathrm{S}^{1} l \mathrm{l}\right\}$ fled from Rm". This is the usual dating formula in the Safaitic inscriptions, in which $s^{I} n t$ "year" is not usually introduced by a preposition. The word $s^{I} n t$ "year" is followed by a memorable occurrence, something somewhat unique: this might be related to the weather such as a flood or snow, or to the death of a particular person, or to disease or many other occurrences. The combination $s^{l} n t$ ngy is not unprecedented, as we shall discuss below. It should be noted that the letter $y$ has been added because it does not exist in the inscription, but it is clear that the name $s^{l} l y$ is intended because of the parallel with AbNSJ 1 which contains the same genealogy and therefore, we suggest, the same reference to $s^{1} l y$.

After the dating formula, the author continues $w h r\{s\} h-s^{l} n t$ "and \{he kept watching \} this year", which is followed by a prayer, $f h b^{1} l s^{1} m n \dot{g} w\{t\}$ "and so O B ' $1 s^{1} \mathrm{mn}$ [grant] help". The combination of this narrative section and prayer indicate that the year in question was a year of drought, since the meaning of hrs in this case may refer to watching for the rain, or watching for the help of $\mathrm{B}^{1} 1 \mathrm{~s}^{1} \mathrm{mn}$, rather than watching out in any other sense, although the semantic range of the verb is too wide for us to be sure. $\mathrm{B}^{1} 1 \mathrm{~s}^{1} \mathrm{mn}$ is the deity usually invoked in prayers for rain, so $\dot{g} w \underline{t}$ "help" here seems to refer to the rain in this context. The phrase $h-s^{I} n t$ always means "this year" in Safaitic (C 1292; SIJ 73).

The word $\mathrm{rm}$ is attested in many Safaitic inscriptions and is often interpreted as referring to Rome or the Romans (C 3688; LP 94; SIJ 352; CSNS 1004; 'Abbādī 2006, p. 79). Therefore the phrase $n g y s^{1} l[y] \mathrm{mn} \mathrm{rm}$ could mean "[S'ly] fled from the Romans". It is interesting that this inscription reads $s^{I} n t n g y s^{l} l[y] \mathrm{mn} \mathrm{rm}$ "the year that [S'ly] fled from Rm" while AbNSJ 1 reads $s^{1} n t$ 'ty $s^{1} l y ~ m-r m$ "the year $\mathrm{S}^{1} l y$ came from Rm". We believe that AbNSJ 1 was written before this inscription, and that perhaps the change of verb from 'ty to $n g y$ represents a development in how his departure from Rm was understood: what was first perceived as "coming" was later reinterpreted with hindsight as "fleeing".

${ }^{3}$ SIJ 73: $w$ hrs $h-s^{l} n t$ (f) $h b^{\prime} l s^{l} m n r w h$, nd he was hungry and cold this year \{and so\} O $\mathrm{B}^{\mathrm{\prime}} \mathrm{l} \mathrm{s}^{1} \mathrm{mn}$ [grant] relief from adversity and uncertainty. 


\section{Prayer}

As mentioned above, the narrative is followed by a prayer section, as is customary for many Safaitic inscriptions. The author invokes the deity B' $1 \mathrm{~s}^{1} \mathrm{mn}$ saying $f h$ $b^{\prime} l s^{l} m n \dot{g} w\{\underline{t}\}\{w\}\left\{s^{1}\right\}\{l\}\{m\}\{w\}\{q\}\{b\}\{l\}\{l\}\{l\}-\{d\}\{\{\}\{h\}\{b\}$ "and so O B'ls' $1 \mathrm{mn}$ [grant] \{help\} \{and $\{$ security $\}$ and [show] \{benevolence $\{$ for $\{$ whoever\} $\{$ 'hb\}". $\mathrm{B}^{1} \mathrm{ls}^{1} \mathrm{mn}$ is known in Safaitic as the god of the sky and is mostly connected to prayers for rain (WH 2143; KRS 1482).

At the end of the inscription, the author asks the deity $B^{1} 1 s^{1} \mathrm{mn}$ to accept his prayer, and apparently he also asks for the prayers of other people to be accepted. This is dependent on the interpretation of the verb ' $h b$. Macdonald has translated the verb ' $h b$ as "who has pursued a sinful course" when dealing with the inscription AbNSJ 1; this interpretation comes from the IV-form of the verb $h w b .^{4}$

The verb $n g y$ is attested in many Safaitic inscriptions, with the formula $s^{I} n t$ $n g y$ occurring more than forty times, and appears to have different meanings in many cases. Three particular meanings should be highlighted, which we shall list here. The first is the meaning attested in WH 1698, $s^{I} n t$ ngy qșr $h-m d n t$ "the year Caesar announced the province". Macdonald has interpreted this verb, and has suggested that the formula $s^{I} n t$ ngy $P N h d y$ should be understood as "in the year that PN was announced leader", which he thinks makes reference to the conscripting of nomads into either the Roman or the Nabataean army. The interpretation is based on the word $h d y$, "leader", since the interpretation of "escape" as we have understood it to mean in this inscription does not make a great deal of sense with reference to a leader (Macdonald 2014, pp. 154-155). A second meaning is the one found in HCH 102.1, s'nt ngy rbb'l "the year Rbb'l escaped". The third meaning is found in LP 424: $s^{1} n t$ ngy mlk $s^{1} l$ th "the year that Mlk retained power". The verb retains the $y$ in the feminine form as well, as evidenced by SIJ 786 which reads ngyt '- mlkt "the Queen was announced". Based on the similarity between this inscription and AbNSJ 1, in which the verb ngy is replaced with 'ty, it seems likely that the meaning referred to here is the meaning "to escape". This is corroborated by the historical record (see below) for it is known that Syllaeus left Rome and returned to the area where the inscription was found.

\section{Inscription 2}

\section{Transliteration}

l mlk bn 's ${ }^{1} l m$

\section{Translation}

By Mlk son of ' $\mathrm{s}^{1} \mathrm{~lm}$

${ }^{4}$ Apparatus criticus to AbNSJ 1 inscrption in OCIANA database. 


\section{Commentary}

This inscription consists only of a genealogy. Both of the names are known from the Safaitic corpus.

\section{Historical Discussion}

The most salient aspect of this inscription is certainly the historical reference to the person of Syllaeus ${ }^{5}$ who is known to have been a very powerful minister under Odobas III, the Nabataean king who ruled from 30-9 BC. The main historical sources for the life of Syllaeus are Josephus and Strabo; the latter was in fact a contemporary of his. He participated in an expedition of the Roman army to Arabia where he became acquainted with Herod the Great, whose sister Salome he attempted to marry but was unable to on account of his refusal to convert to Judaism as was demanded by Herod (Bowersock 1983, pp. 47-53). Syllaeus also played a role in the revolution of southern Syria in 12 BC; Strabo in his records of this affair blames Syllaeus for the failure of the rebellion (Strabo, Geography, 16.4.24). Although a powerful figure in Rome, Syllaeus fell into some trouble there in later years when accusations were famously brought against him by Aretas IV. Herod's ambassador Nicolaus accused him before Augustus, and both he and Aretas accused Syllaeus of poisoning Obedas III, among other charges; by accusing him of bearing false witness to Augustus concerning Herod, they attempted to damage his political career. In another reference to Syllaeus, found in Josephus's Jewish War, the narrative portrays him yet again as plotting against Herod. The date of his death is controversial, as it is unclear whether he died in $9 \mathrm{BC}$ or $6 \mathrm{BC}$, but it seems that he was executed (Josephus 1981, I, pp. 490-631). It is possible that after the death of Obodas III, Syllaeus ruled in his place, but this is uncertain and the matter is obscured by the various accounts of when he died.

'Abbādī (1996) writes in his commentary on AbNSJ 1 that the event referred to is the coming of Syllaeus from Rome in 12-9 BC, and links this to another inscription from the same wadi (AbSHYN 1) which mentions $s^{1} n t h r b n b t$ yhd "the year of the Nabataean-Jewish war", which he now considers to be a reference also to the coming of Syllaeus to the region and not to any of the other wars from the historical record which would fit this description.

\section{Conclusion}

It seems likely that Syllaeus was aware of the imminent death of Obodas III, and that this was his motivation for leaving the Nabataean kingdom for Rome in order to become close to Augustus and therefore place himself in a position to inherit the Na-

\footnotetext{
${ }^{5}$ While we provide here a brief overview of the person of Syllaeus, for more detailed discussion see 'Abbādī (2001); Al-Rawabdeh (2015).
} 
bataean throne. Aretas IV, on the other hand, was from the military and he in fact took power in Petra and attempted to rule the Nabataean kingdom, but without the permission from Rome. Ultimately Aretas IV may have proved a better candidate to serve the Roman interests in Arabia. Our hypothesis is that when Syllaeus became aware that Rome was more likely to install Aretas IV as king in Nabataea, he then fled Rome and returned to Arabia, hence the occurrence here of the verb ngy, "he escaped".

\section{Acknowledgements}

We thank the anonymous reviewers for their constructive comments. We are grateful to Mr M. C. A. Macdonald of Oxford University for reading and commenting upon this paper.

\section{Sigla}

$\begin{array}{ll}\text { AbNSJ } & \text { 'Abbādī, Ș. (2001). } \\ \text { AbSHYN } & \text { 'Abbādī, Ș. (1996). } \\ \text { C } & \text { Ryckmans, G. (1951) } \\ \text { CSNS } & \text { Clark, V. A. (1979). } \\ \text { HCH } & \text { Harding, G. L. (1953). } \\ \text { KRS } & \text { Safaitic inscriptions in King (unpublished). } \\ \text { Lp } & \text { Littmann, E. (1943). } \\ \text { SIJ } & \text { Winnett, F. V. (1957). } \\ \text { WH } & \text { Winnett, F. V. - Harding, G. L. (1978). }\end{array}$

\section{References}

'Abbādī, Ș. (1996): Nuqūšs șafawiyyah ğadīdah fî '1-urdun / wādī al-ḥašād. Dirasat al- 'ulum alinsāniyyah wa-'l-iğtima 'iyyah Vol. 23, pp. 242-252.

'Abbādī, Ș. (1997): Naqš șafawī ğadīd yu'arrahu ilà al-rub' al-ahīr min al-qarn al-awal qabl almīlad. Abḥât al-yarmūk. Silsilat al- 'ulum al-insāniyyah wa-'l-iğtima 'iyyah Vol. 13, No. 3, pp. 141-151.

'Abbādī Ș. (2001): A New Safaitic Inscription Dated to 12-9 BC. In: Studies in the History and Archaeology of Jordan, Vol. 7, pp. 481-484. Amman, Department of Antiquities of Jordan.

'Abbādī, Ș. (2006): Nuqūš șafawiyyah min wādī salmā (al-bādiyah al-urduniyah). Amman, Badia Research and Development Center.

Al-Jallad, A. (2015): An Outline of the Grammar of the Safaitic Inscriptions. Leiden-Boston, Brill (Studies in Semitic Languages and Linguistics 80).

Al-Rawabdeh, R. (2015): About the Nabataean Minister Syllaeus from New Silver Coins. Mediterranean Archaeology and Archaeometry Vol. 15, No. 1, pp. 73-82.

Anderson, B. (2009): Double-Crossing Jordan: Strabo's Portrait of Syllaeus and the Imagining of Nabataea. Studies in the History and Archaeology of Jordan Vol. 10, pp. 391-397. Amman, Department of Antiquities of Jordan.

Bowersock, W. (1983): Roman Arabia. Cambridge, Mass. - London, Harvard University Press. 
Clark, V. A. (1979): A Study of New Safaitic Inscriptions from Jordan. Thesis Presented for the Degree of Doctor of Philosophy, Department of Middle Eastern Studies, University of Melbourne. Ann Arbor, MI: University Microfilms International.

Harding, G. L. (1953): The Cairn of Hani'. Annual of the Department of Antiquities of Jordan Vol. 2, pp. $8-56$, pls $1-7$.

Josephus, F. (1981): The Jewish War. Translated by G. A. Williamson (Geoffrey Arthur), 18951982. / Smallwood, E. Mary, 1981. (Rev. ed.) revised with a new introduction, notes and appendixes by E. Mary Smallwood. New York, Dorset Press.

King, G. M. H. (unpublished): Basalt Desert Rescue Survey (to be published in The Online Corpus of the Inscriptions of Ancient North Arabia).

Littmann, E. (1943): Safaitic Inscriptions. Syria. Publications of the Princeton University Archaeological Expeditions to Syria in 1904-1905 and 1909. Division IV. Section C. Leiden, Brill.

Macdonald, M. C. A. (1993): Nomads and the Hawrān in the Late Hellenistic and Roman Periods: A Reassessment of the Epigraphic Evidence. Syria Vol. 70, pp. 303-413.

Macdonald, M. C. A. (2006): Burial between the Desert and the Sown: Cave-tombs and Inscriptions near Dayr Al-Kahf in Jordan. Damaszener Mitteilungen Vol. 15, pp. 273-301.

Macdonald, M. C. A. (2014): Romans Go Home? Rome and Other 'Outsiders' as Viewed from the Syro-Arabian Desert. In: Dijkstra, J. H. F. - Fisher, G. (eds): Inside and Out. Interactions between Rome and the Peoples on the Arabian and Egyptian Frontiers in Late Antiquity. Leuven, Peeters (Late Antique History and Religion 8).

Ryckmans, G. (1951): Corpus Inscriptionum Semiticarum: Pars Quinta, Inscriptiones Saracenicae Continens: Tomus I, Fasciculus I, Inscriptiones Safaiticae. Paris, E Reipublicae Typographeo.

Strabo (1924): Geography. Translated by Honorace L. Jones. Cambridge, Harvard University Press.

Winnett, F. V. (1957): Safaitic Inscriptions from Jordan. Toronto, University of Toronto Press (Near and Middle East Series 2).

Winnett, F. V.-Harding, G. L. (1978): Inscriptions from Fifty Safaitic Cairns. Toronto, University of Toronto Press (Near and Middle East Series 9). 